\title{
JUURNAL.RU
}

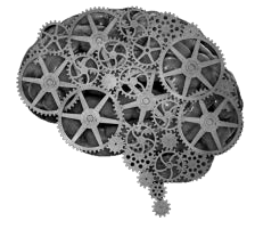

COMPANY GROUP "INTELLEKT"

\author{
Скрипник К.В. \\ Московский государственный областной университет \\ Москва, Россия
}

doi: 10.18411/lj2016-6-5-04

\section{Категории модальности и персональности в рекламном слогане как типе текста (на материале английского языка)}

Язык рекламного слогана имеет особенную референцию: во-первых, отбор языковых единиц формируется прагматической направленностью рекламного сообщения (при помощи языковых выразительных средств, экспрессивных пунктуационных конструкций синтаксиса); во-вторых, структура и прагматическая установка рекламного слогана указывает на рекламные средства образности (вербальные и невербальные).

Данная статья посвящена систематизации полученных ранее данных о слоганеи рассмотрению функционирования грамматическихкатегорий модальности и персональности в слогане как типе текста. Объектом исследования являются рекламные слоганы. Предмет настоящего исследования - текстовые категории, формирующие слоган. Материалом для исследования послужили 300 рекламных слоганов на английском языке, размещенные в сети Интернет $[1,2,3]$.При анализеиспользуются методы наблюдения и сопоставления языковых фактов,описательный метод, комплексная методика лингвистического анализа: словообразовательный, лексический и синтаксический анализ текстов.

Термин «слоган» происходит от галльского языка и означает «боевой клич». В 1880 годуон впервые встречается в современном значении. В «Словаре терминов по рекламе, маркетингу, Atl, Btl и PR.» А. Ульянова даётся следующее 
определение слогана - рекламный лозунг: четкая, ясная и сжатая формулировка рекламной идеи,которая легко воспринимается и запоминается[4].Исходя из данного определения, можно говорить о том, что рекламный слоган по своей структуре бесспорно отличается от других типов рекламного дискурса. Прежде всего - своей краткостью.

Многие исследователи (Володина М.Н., Добросклонская Т.Г., Лившиц Т.Н.) выделяют рекламные тексты как жанр текстов массовой коммуникации, так как онииздаются в СМИ, звучат по радио и телевидению[5, 6, 7]. Например, Филимонов А.В. к жанрам политической рекламы причисляет листовки, брошюры, плакаты, Интернет баннеры, прямые Интернет и почтовые рассылки, теле- и радиоролики [8].

Наличие ряда рекламных жанров свидетельствует о существовании подстиля языка массовой коммуникации, характеризующегося наличием совокупности инвариантных признаков. Автор статьи присоединяется к мнению тех учёных (Добросклонская Т.Г., Лившиц Т.Н., Шидо К.В.), которые рассматривают рекламный текст как подстиль языка массовой коммуникации, гармонично сочетающего в себе элементы разных стилей $[6,7,9]$.

Слоган как рекламный жанр определяется наличием языковых средств и фигур речи из разных стилей, таких как художественного, разговорного, в меньшей степени научного. При его создании широко применяются наиболее характерные компоненты указанных стилей. Так, на фонетическом уровнеинвариантными признаками является применение таких приемов, как аллитерация, ассонанс, конечная рифма [6, 9]; на лексическом уровнеиспользование метафоры, метонимии, феномена многозначности слова [9]; на структурно-синтаксическом уровне выделяются конструкции с одной и двумя предикативными основами, а на уровне стилистического синтаксиса используются риторический вопрос, эллиптические конструкции, параллелизм, анафора, эпифора, восклицательные предложения, инверсия, открытые конструкции [10]. Эти выразительныесредства языкаимеют 
особоезначение среди системообразующих средств художественного стиля. Фонетическая редукция вспомогательных глаголов и эллипсис, встречающиеся в слоганах - это неотъемлемые элементыразговорного стиля.[9]Взаимосвязь жанра рекламного слогана с научным стилем находит отражение при использовании терминологической лексики[9].

Единицы всех языковых уровней (фонетического, лексического, синтаксического, графического)активно взаимодействуют друг с другом в рекламном лозунге, что приводит к гиперэкспрессии - комбинаторики средств, увеличивающихвыразительность текста.

Основными актуализаторами, осуществляющими корреляцию художественного текста с внетекстовой действительностью, в лингвистике текста принято считать текстовые категории темпоральности, локальности, модальности, персональности, референтности и т.д. В настоящей статье автор рассматривает архитектонику английских слоганов по следующим грамматическим признакам: модальность и персональность, в основе каждой из них просматривается взаимосвязь средств языка, принимающих участие в образовании типологических инвариантных признаков текста и служащих для определенного семантического содержания.

Под модальностью А.А. Елисеева понимает текстовую категорию, в которой с помощью морфологических, лексических, лексико-синтаксических средств и экстралингвистических факторов выражается субъектно-оценочное отношение автора к объективной реальности, отражённой в тексте, формирующую грамматический тип текста в плане его модальной структуры. Выделяются следующие признаки $[11,26]$ :

1. Модальная детерминация описываемых событий - варианты соотношения объективных событий с языковыми.

2. Системность модального построения текста - наличие модальных подсистем автора и персонажей. 
3. Модальный тип текста -полимодальные или мономодальные тексты.

4. Стержневая форма модальногопостроения текста.

5. Однородный или неоднородный тип текста с точки зрения основного средства выражения модальности.

6. Степень насыщенности текста средствами, выражающими модальность.

Модальную архитектонику текста можно представить в виде совокупности языковых средств морфологического, синтаксического и лексического уровней, обеспечивающих ориентацию слушателю или читателю в модальном плане функционального мира созданного текста [11, 84].

Рекламный слоган не принадлежит к категории текстов, где возможна речь персонажей наряду с речью автора, но в эмоциональном плане она всегда ярко выражена. Например,

Dirty mouth? Nothing cleans it up like Orbit;

Not trying it would be a Greek tragedy. CARTE D’OR ice-cream;

Maybe she’s born with it... Maybelline.;

See what you're missing. Epson printers.

Simplicity is making hospitals feel less like hospitals. Philipsequipment.

Модальная архитектоника данных рекламных слоганов определяется как детерминированная, мономодальная (наличие одной формы склонения изъявительное (the Indicative Mood), или повелительное (the Imperative Mood), или сослагательное (the Subjunctive Mood)), односистемная (наличие только речи автора) и имеет глагольный характер(однородный) в сочетании с глагольно-адвербиальным типом (неоднородным).

Категория персональности на текстовом уровне связана с такими языковыми средствами, которые обладают признаком наличия лица или содержат ссылку на него. Это могут быть личные местоимения, личные формы глагола, притяжательные местоимения, императив, модальные глаголы, 
вопросительные предложения или другие единицы, имеющие ссылку на лицо. Данная категория имеет ряд инвариантных признаков [11, 33]:

1. Детерминированность (постоянное присутствие в тексте языковых средств с семой «персональность»).

2. Одно- или двухсистемность - речь автора и персонажей.

3. Моно- или полиперсональность (учет единого или разных лиц повествования).

4. Однородность или неоднородность персональности (наличие различных языковых средств с семой «персональность»).

В рекламных слоганах присутствуют личные и притяжательные местоимения (I don’t want to grow up... Toys 'R' Us; Live your life, love your home. IKEA; We keep your promise. DHL), повествовательное (It is a pleasure to eat good meat. Campbell's) и повелительное наклонения (Stopseeingbrokenhaireverywhere. Pantene), т.e. предполагается наличие собеседника, к которому оно адресовано. Категория лица, оформленная через императив, достаточно часто встречается в данном типе текста в форме обращения к читателю/слушателю (See what you're missing. Epson printers). Bce эти художественные приемы важны для смыслового аспекта рекламного слогана, ведь основная его цель пробудить интерес адресата. Таким образом, персональная структура рекламного слогана становится детерминированной (т.е. имеет конкретные языковые единицы для выражения категории лица), односистемной (только план автора), моноперсональная, неоднородная.

По результатам проведенного анализа англоязычных рекламных слоганов на наличие таких текстовых категорий, как модальность и персональность мы можем сделать следующие выводы:

1. Рассматриваемые примеры показали, что анализ текстов слогана сводится к таким модальным характеристикам, как: мономодальность, односистемность, неоднородность. 
2. Персональная архитектоника данного типа текста определяется как детерминированная, прономинальная - категория лица выражена местоимениями, односистемная (только план автора), моноперсональная, неоднородная (включает в себя разные группы местоимений, личные формы глаголов).

Рассмотренные категории текстов рекламного слогана отражает признаки функционального стиля, жанра и типа текста. Полный анализ этих признаков и сведение их в единую систему позволит приоткрыть тайну превращения слогана в микротекст. 


\section{Литература:}

177 catchy and creative slogans //Hongkiat. [website] [Electronic resource] URL:http://www.hongkiat.com/blog/77-catchy-and-creative-slogans/(дата обращения: 20.12.2014)

240 best advertising slogans modern brands.//Advergize. [website] [Electronic resource] - URL:http://www.advergize.com/advertising/40-best-advertisingslogans-modern-brands/(датаобращения: 20.12.2014)

3 Adslogans [website] [Electronic resource] - URL:http: // www. adslogans. co.uk. /(датаобращения: 20.12.2014)

4 Ульянов А. Словарь терминов по рекламе, маркетингу, Atl, Btl и PR. - M., 2007

5 Володина М.Н. Язык СМИ - основное средство воздействия на массовое сознание// Язык СМИ как объектмеждисциплинарного исследования. - М.: Изд-воМГУ, 2003, с.9-31

6 Добросклонская Т.Г. Вопросы изучения медиа-текстов-М.: Диалог-МГУ: МАКС-ПРЕСС, 2000.- 287c.

7 Лившиц Т.Н. Реклама в прагмалингвистическом аспекте - Таганрог, 1999

8 Филимонов А.В. Риторические особенности политической рекламы. Автореф. канд. дис. - М., 2009 - 194 с. /Научная библиотека диссертаций и авторефератов disserCat [Электронный pecypc]. URL: http://www.dissercat.com/content/ritoricheskie-osobennosti-tekstapoliticheskoi-reklamy (дата обращения: 10.01.2016)

9 Шидо К.В. Рекламный слоган как особый жанр английских рекламных текстов. - Автореф. канд. дис. - Саратов, 2002 - 194 с. Диссертации по гуманитарным наукам [Электронный pecypc]. URL: http://cheloveknauka.com/reklamnyy-slogan-kak-osobyy-zhanr-angliyskihreklamnyh-tekstov\#ixzz3yGJo6HY7 (дата обращения: 10.01.2016) 
10 Скрипник К.В. Презентация средств синтаксического уровня как инвариантный признак рекламного слогана (на материале английского и китайского языков) // Вестник Московского государственного областного университета. Серия: Лингвистика. 2015. № 3. С. 137-142.

11 Левченко М.Н. и др. Интерпретация текста и его грамматических моделей (типологический аспект): монография.М.: Изд-во МГОУ, 2013. - 240 с. 